\title{
INDUSTRI HALAL: MENGEMBANGKAN HASRAT DAN LOGIKA KONSUMSI
}

\author{
Saepul Bahri ${ }^{1}$, Deden Hidayat ${ }^{2}$, Agus Nurcholis Saleh $^{3}$ \\ Universitas Mathla'ul Anwar Banten \\ J1. Raya Labuan KM 23 Kec. Saketi Kab.Pandeglang Banten, Indonesia \\ Korespondensi Author: muruypisan@gmail.com
}

\begin{abstract}
This paper is actually the author's desire to contribute to the idea of halal thought initiated by most of the world's Muslims, the author does not interpret halal simply and narrowly but the author tries to interpret halal by changing the paradigm of Muslims that halal must be expanded into a halal industry. in this world. This paper inspires especially Muslims in Indonesia to have the courage to create new halal industries, developed in various aspects of the needs of the wider community. In this paper the author shows how great the potential of the halal industry is, but it must be driven by politics and productive market mechanisms. According to the author's research, the halal industry is actually a religious commandment, namely Islam, but more importantly the substance of the halal industry is to develop the desire and logic of consumption, why because the halal industry will progress and develop depending on the consumer who consumes goods, if the desire and logic of consumption is weak, then as good and as productive as any halal industry will not develop and experience progress, therefore the desire and logic of consumption is very important to be understood by Muslim entrepreneurs who will develop the halal industry.
\end{abstract}

Keywords: Halal Industry, Islam, Desire, Consumption Logic

\begin{abstract}
Abstrak: Tulisan ini dibuat sesungguhnya merupakan keinginan penulis untuk memberikan kontribusi terhadap gagasan pemikiran halal yang digagas oleh sebagian besar umat Islam dunia, penulis tidaklah memaknai halal secara sederhana dan sempit tetapi penulis mencoba memaknai halal dengan merubah paradigma umat Islam bahwa halal harus diluaskan menjadi industry halal di dunia. Tulisan ini menggugah khususnya umat Islam yang ada di Indonesia agar berani menciptakan industri-industri halal yang baru, dikembangkan dalam berbagai aspek kebutuhan masyarakat luas. Dalam tulisan ini penulis menunjukan betapa potensi industry halal sangat besar sekali, namun harus didorong dengan politik dan mekanisme pasar yang produktif. Menurut penelitian penulis, industry halal sejatinya adalah perintah agama yaitu Islam, tetapi yang lebih urgen lagi substansi dari industry halal adalah mengembangkan hasrat dan logika konsumsi, mengapa karena industry halal akan maju dan berkembang tergantung dari consumer yang mengkonsumsi barang, apabila hasrat dan logika konsumsi lemah, maka sebaik dan seproduktif apapun industry halal tidak akan berkembang dan mengalami kemajuan, oleh karena itu hasrat dan logika konsumsi sangat penting dipahami oleh para pengusaha-pengusaha muslim yang akan mengembangkan industry halal.
\end{abstract}

Kata Kunci : Industry Halal, Islam, Hasrat, Logika Konsumsi 


\section{PENDAHULUAN}

Industry halal adalah sebuah konsep yang menarik untuk dikaji bukan saja oleh umat Islam yang ada di Indonesia tetapi oleh umat Islam diseluruh dunia. Para penulis dari berbagai universitas yang ada di Indonesia dan dunia pun banyak menulis tentang industry halal, halal tidak hanya membahas tentang kualitas makanan menurut aturan agama, tetapi halal pula berkembang menjadi sebuah Industri, fenomena ini sangat menarik, karena perkembangan umat Islam yang begitu pesat di dunia, umat islam di sebuah Negara membutuhkan label halal bukan saja terhadap makanan yang mereka makan tetapi seluruh sendi-sendi kehidupan membutuhkan nya, sector-sektor public, jasa, kesehatan, perdagangan, produk harus menunjukan kehalalan.

Penulis memandang persoalan Industri halal yang mengemuka di dunia saat ini adalah optimalisasi dan pengembangan industry halal yang tidak dilakukan secara serius. Umat Islam di sebuah Negara terlalu mengandalkan pemerintah untuk mengembangkan industry tersebut, mereka beralasan bahwa hal tersebut adalah tugas pemerintah bukan tugas warga Negara. Logika umat Islam di sebuah Negara sangat parsial dan terkesan acuh, begitupula dengan umat Islam di Indonesia, mereka terjebak kedalam dominasi Negara, kementrian agama dan MUI (Majlis Ulama Indonesia) untuk mengembangkan industry halal.

Gerakan umat Islam di Indonesia untuk memobilisasi industry halal sangat lemah, media social hanya dilakukan untuk isu-isu politik semata, padahal apabila gerakan industry halal di lakukan oleh umat islam di medsos begitu gencar dapat merubah stigma masyarakat dan pemerintah. Penulis melihat itulah kelemahan umat Islam di Indonesia, presentasi umat Islam kearah perkembangan ekonomi sangat kurang dibanding presentasi terhadap politik, hukum dan masalah system pemerintahan.

Umat Islam akan tersinggung apabila seseorang menistakan agamanya, umat Islam akan marah apabila sunatullah dilanggar, penulis tidak ragu bahwa itu adalah perjuangan penegakan agama, tetapi agama Islam pun memulyakan umatnya yang berjuang secara ekonomi untuk meningkatkan tarap hidupnya, umat Islam kalah bersaing dengan pengushapengusaha non muslim, bahkan pengusaha non musim menguasai Indonesia. Penulis tidaklah memprovokasi pengusha muslim tetapi pengusaha muslim memiliki peluang cukup besar karena di Indonesia mayoritas penduduknya beragama Islam dan itu adalah potensi dan peluang.

Penelitian industry halal banyak dilakukan seperti Cucu Susilawati dalam International Journal of Nusantara Islam " Role of The Halal Industry in Recovering the National Economy in covid -19 Pandemic" ia membuktikan bahwa Industry halal menjadi lebih kuat pada pandemic covid-19 dengan argumentasi bahwa industry halal memiliki beberapa sector yaitu keuangan halal, mkanan halal, busana halal. Dan menurutnya industry halal memberi kontribusi 40 persen dalam ekonomi Indonesia dan sector yang berpengaruh adalah Bank Konvensional (Susilawati, 2020). Ratna Komalasari dalam Jurnal Ekonomi 
Syariah "How Does Halal Food on Your Plate Punch Indonesia's economy”, ia menjelaskan bahwa makanan halal berpengaruh sangat besar terhadap ekonomi Indonesia (Komalasari, 2020). Faqiyatul Mariya Waharini dalam Jurnal al-Iqtisad “ Model Pengembangan Industri Halal Food di Indonesia" ia membuktikan peranan Bank syariah dalam industry halal terutama dalam proses produksi yang memiliki tiga tahapan yaitu halal Integrity, halal logistic dan halal verification (Waharini, 2018).

M Aulia Rahman \& Syamsuddin dalam al-Muqtasid " Halal Industry In Indonesia: The role of Sharia Financial Intitutions in Driving Industry and Halal Ecosystem" ia menegaskan bahwa Lembaga Keuangan Syariah (LKS) memiliki peran penting untuk menjembatani antara unit deficit dan surplus dalam praktek ekonomi syariah (Rahman \& Syamsudin, 2019). Hadi Peristiwo dalam Journal of Islamic Studies and Humanities “ Indonesia halal Food Industry: Development opportunities and Challengers on Halal Supply Chains" ia menemukan bahwa persaingan kebutuhan makanan halal lebih tinggi, oleh karenanya permintaan makanan halal harus mempertahankan produksinya dengan aplikasi dan merespon konsumen dengan cepat, dan ia pun menemukan bahwa lemahnya pemanfaatan industry halal di Indonesia (Peristiwo, 2019).

Pada tulisan ini sesungguhnya penulis berlainan dengan penelitian sebelumnya, penulis ingin menegaskan dan merubah stigma lama yakni bahwa halal dan baik hanyalah berhubungan dengan makanan saja, tetapi seluruh aspek kehidupan manusia harus berpedoman kepada halal dan baik, seperti system industry halal, bioteknologi, pariwisata, produk perawatan, bank, frofesi, penggadaian, bahkan system ekonomi pun harus halal dan baik. Halal bukan saja penyeleksian dan penentuan terhadap sesuatu yang dikonsumsi manusia tetapi proses untuk menghasilkan yang dikonsumsi tersebut haruslah halal dan baik pula.

Produk-produk yang dihasilkan oleh industry haruslah berdasarkan mekanisme halal dan baik. Selanjutnya perlu ditegaskan bahwa bangsa Indonesia yang mayoritasnya beragama Islam, penguatan industry halal haruslah menjadi prioritas. Penulis berkeyakinan bahwa apabila Industri halal ini di utamakan di Indonesia akan memperkuat ekonomi Indonesia, akan mengangkat ekonomi makro dan mikro serta menjadikan bangsa Indonesia adalah bangsa yang mandiri, kaya yang terbebas dari hutang, bahkan mampu menyaingi industry-industri dunia yang tidak menerapkan system tersebut.

Kemudian yang menjadi perbedaan dengan penelitian sebelumnya adalah kajian utama dalam tulisan ini menjelaskan kepada pembaca bahwasanya industry halal akan maju dan berkembang apabila para pengusaha Muslim yang ingin mengembangkan industry halal tersebut mengetahui dan memahami hasrat dan logika konsumsi manusia terhadap pasar. Hasrat adalah keinginan dan rasa yang kuat dari konsumen terhadap produk-produk dan fasilitas industry halal yang mereka peroleh dan harapkan, semakin kuat sebuah hasrat maka semakin memungkinkan untuk menbuat dan mengembangkan industry halal, selain draipada hal tersebut di dalam pasar pun dibangun logika konsumsi yang baik yang berhubungan 
dengan industry halal. Sedangkan logika konsumsi adalah logika sosial dan logika hasrat para konsumen dengan nalarnya mensifati terhadap produk-produk yang diciptakan oleh Industri halal.

Eksistensi industry halal dunia sangat langka, kalah bersaing dengan industry kapitalis yang menguasai dunia, lembaga jaminan halal tingkat dunia pun belum ada, padahal sangat berhak sekali Islam memiliki lembaga yang memiliki otoritas terhadap jaminan industry halal. Kemudian para pemeluk agama iain pun tidaklah khawatir karena tujuan utama dari industry halal adalah menciptakan tatanan industry dunia yang berlandaskan syari'ah Islam, dibolehkan dan diterim oleh manusia lalu menciptakan produk yang bersih, sehat tidak rusak tidak membahayakan fisik dan akal serta aman dikonsumsi. Sesungguhnya tantangan industry halal pada arus globalisasi ini berasal dari kaum Sekuler. Kaum Sekuler berpendapat bahwa hak-hak dan kewajiban orang beragama adalah privasi antara individu dengan Tuhannya.

Kaum Sekuler berargumen ranah agama adalah ranah personal, bukan ranah public atau Negara, sedangkan ranah Negara adalah melindungi seluruh warga Negara yang multi agama dibawah satu ikatan yaitu nasionalis dan keadilan sosial, posisi agama berada dibawah supermasi kedaulatan dan hukum Negara. Negara-negara Sekuler menolak dengan tegas supermasi agama diatas Negara, mereka memisahkan antara agama dengan Negara. Argumentasi Negara Sekuler sangatlah kuat karena Negara mereka terdiri dari multi agama, mereka menjamin kebebasan warga negaranya untuk beragama maupun tidak beragama, apabila peran agama sangat superior maka disintegrasi sangatlah kuat, perpecahan sangat jelas, ekonomi buruk, dukungan dunia luar hancur, mereka lebih menjaga harmoni antar agama, peningkatan ekonomi Negara ituah yang utama, kebijakan fiscal dan moneter haruslah terus menguat dan seimbang, mereka akan kebingungan ketika kondisi ekonomi Negara ambruk. Mereka akan nyaman ketika infrastruktur sangat modern dan elegan.

Halal adalah aturan makanan dalam agama Islam, buku yang ditulis oleh Febe Armanios \& Bogac Ergene yaitu Halal A History Food menjelaskan tentang hubungan aturan makanan dan Islam, lebih sfesifiknya lagi dalam buku tersebut persetujuan tentang substansi dan praktek makanan halal dalam tradisi Islam, kemudian buku tersebut mengexplor tentang halal versus haram dan hubungan antara identitas Islam dan yang lainnya (Armanios \& Ergene, 2018). Florence et al dalam bukunya Halal Metters, Islam, politics and Markets in Global Perspective menfokuskan bagaimana pasar halal dilembagakan, karena dalam perkembangan global industry halal tidak hanya tentang makanan tetapi juga tentang bioteknologi dan produk baru, hal ini berdasarkan penelitiannya karena peran Muslim sudah memasuki arena internasional. Johan Fischer dalam bukunya Halal Frontier Muslim Consumers in A Globalized Market buku ini menjelaskan fenomena yang terjadi di London yaitu terdapat dua fenomena yang penting di London warga London terbagi menjadi secular dan kaum agamawan salah satunya adalah agama Islam. Pada bulan November 2005 dan diikuti tahun-tahun selanjutnya, umat Islam di London melakukan 
konfrensi yang disebut Word Food Market (WFM) di London dan juga mengadakan seminar halal yang bertemakan "ethnic food or Word Food Market", kemudian membentuk sebuah aturan tentang pasar halal dan Industri halal di Inggris dan WFM berkembang menjadi organisasi Islam,Group lembaga Produk sertifikasi hala di Inggris yang memahami tentang praktek halal.

\section{METODE}

Penelitian ini menggunakan metode kualitatif dengan study fenomenologis yaitu mengangkat persoalan yang menjadi isu isu utama permasalahan tentang Industri halal. Penekanan penelitian ini dengan mengkaji, membaca, mencatat dan menguji kepustakaan berupa buku, jurnal, majalah dan surat kabar online. Teknik pengumpulan data yang diambil adalah data-data yang diperoleh dari kajian literature berupa data primer dan data secunder. Data primer berupa fakta-fakta industry halal di Indonesia dan data secunder berupa pendapat dan argumentasi para akademisi yang dipublikasikan melalui buku, jurnal, majalah dan surat kabar online.

\section{HASIL DAN PEMBAHASAN}

Islam, Politik dan Pasar

Semua manusia diseluruh dunia memahami apabila ucapan, tertuliskan didalam makanan dan produk yaitu kata "halal"maka mereka semua mengetahui dan tidak berfikir banyak bahwa hal tersebut adalah label/ symbol dan ajaran Islam. Halal adalah ajaran agama Islam yang wajib dilaksanakan oleh seluruh umat Islam. Tidak melaksanakannya disebut umat yang ingkar. Seluruh umat Islam tunduk dan patuh kepada aturan agama yaitu kata halal, karena aturan tersebut berasal dari Allah, dan aturan Allah sudah pasti kebenarannya, posisi ilmu pengetahuan adalah setelah meyakini kebenaran firman Allah tersebut (teks diatas akal).

Umat Islam meyakini konsep halal merupakan kebaikan dan kasih sayang Allah kepada umatnya, Allah memberikan pelajaran dan peringatan yang hebat ini demi mempertahankan hidup dan kelangsungan manusia didunia. Sebegitu pentingnya konsep halal dalam ajaran Islam para umat Islam di Negara lain yang mana Islam sebagai minoritas di Negara tersebut pun memilih dan menentukan makanan tidak sembarangan, mereka menuntut Negara agar melindungi hak-hak minoritas sebagai warga Negara, salah satunya dengan menuliskan lebel halal di setiap makanan yang diproduksi dan layak dikonsumsi oleh dirinya dan keluarganya (Armanios \& Ergene, 2018).

Konsep halal dalam bagi umat Islam merupakan perintah langsung dari Tuhan, karena disetiap kata perintah wajib dilaksanakan "al-amru lil wujub” (setiap perintah adalah wajib) dan dalam Al-Qur'an banyak menjelaskan tentang al-amr tersebut seperti kata “ quluu" adalah perintah yang artinya makanlah, kemudian didalam Al-Qur'an pun bukan saja terdapat amr tetapi terdapat juga penjelasan tentang an-nahyu (yaitu larangan), lalu didalam 
Al-Qur'an pun terdapat penjelasan tentang al-Ibahah (kebolehan). Perintah dan larangan yang sangat jelas dalam Al-Qur'an disebut dengan qat'I maka tidak diperlukan Al-Hadits, Al-Hadits diperlukan sebagai penegasan, sedangkan perintah dan larangan yang belum jelas dalam Al-Qur'an disebut dengan dzani maka peran Al-Hadits sangat diperlukan sekali sebagai referensi memutuskan kebolehan perintah dan ketidak bolehan dalam larangan, dan konsep halal dalam Al-Qur'an terutama tentang makanan sebagaimana telah disebutkan diatas adalah $q a t^{\prime} i$.

Lalu mengapa Allah berfirman didalam Al-Qur'an menegaskan yang halal dan haram, menurut pemahaman penulis, Allah menegaskan konsep halal dan haram dalam kehidupan manusia tujuannya adalah untuk memulyakan dan memberi pengetahuan bagi manusia betapa kasih sayang Allah maha luas. Allah mempertahankan manusia karena manusia diamanatkan oleh Allah sebagai pemimpin/khalifah di Bumi. Kemudian Allah tidaklah melupakan aspek sosial dan etika hubungan manusia dengan alam, dengan konsep halal diharapkan manusia mampu memelihara dirinya, keluarganya, masyrarakat dan lingkungan sekitarnya dari kerusakan yang disebabkan manusia itu sendiri. Konsep halal meligitimasi sumber-sumber otoritas budaya umat Muslim, sehingga bukan saja sebagai ajaran agama tetapi menjadi identitas Muslim itu sendiri.

Dikarenakan halal adalah identitas seorang Muslim, maka didalam makna halal terdapat nilai-nilai yang dibangun, nilai-nilai itu muncul bukan saja sebagai penanda, tetapi produktif secara ucapan dan perlakuan. Nilai-nilai dalam makna halal adalah esensialis yaitu mempertahankan substansi dari makna halal tersebut, nilai-nilai itu tidak tercampur dengan makna lain karena sudah menjadi budaya. Kokohnya nilai-nilai didalam makna halal tersebut yaitu penegasan makna halal didalam Al-Qur'an yang di definisikan dengan kebolehan yang tidak bertentangan dengan syariah. Disisi yang lain nilai-nilai yang melekat pada makna halal adalah penjelasan tentang makanan yang halal dan baik menjadi esensialis, karena definisi yang melekat pada makna makanan yang halal dan baik adalah makanan yang bersih, tidak rusak dari zatnya, tidak membahayakan fisik, sehat, aman dari mikroba dan pathogen serta bebas dari zat-zat kimia, racun yang berbahaya.

Nilai-nilai halal dan makanan halal yang baik dibangun dan berpengaruh sangat kuat terhadap arus konsumsi manusia, nilai-nilai tersebut merubah pemaknaan tentang konsumsi makanan, bukan saja umat Islam tetapi umat manusia di dunia mengalihkan konsumsi manusia pada makanan yang halal dan baik, mereka terpengaruh dengan konsep Islam tentang makanan, mereka mengkonsumsi karena yakin apabila mengkonsumsi makanan yang berlebel halal yang di tegaskan umat tidak ada bahaya dan aman di konsumsi sebagaimana telah dijelaskan diatas.

Keraguan mereka tentang penyakit dan bahan kimia serta racun yang terdapat dalam makanan tersebt menjadi hilang. Tentunya pelebelan halal tersebut bisa dirasakan manfaatnya bukan saja oleh umat Islam, tetapi oleh umat lainnya. Penulis berkeyakinan bahwa agama lain pun setuju dengan konsep halal dan makanan halal yang baik yang 
ditegaskan dalam Islam, walaupun terdapat perbedaan dari sisi doktrin ajaran, tetapi demi kesehatan dan gizi manusia di dunia mereka pun mempercayai Islam dengan konsepnya. Umat Islam minoritas di sebuah Negara tidaklah khawatir untuk memilih makanan, karena Negara tersebut membela hak-hak mereka sebagai agama Islam, artinya pemerintah di Negara tersebut mendukung labelisasi pada makanan dengan melebelkan kata halal.

Tentunya pandangan penulis halal dalam arus globalisasi tidak cukup mengkaji dan menetapkan makanan semata, tetapi lebih jauh dari itu seluruh unsur yang berhubungan dengan industry seperti jasa, lingkungan, parawisata, bioteknologi, manufaktur, pangan perdagangan, human life dll, tidak terlepas dari unsur halal dalam bingkai industry halal. karena umat Islam sudah memasuki ranah internasional, umat Islam telah memutuskan untuk menghindari alcohol, agar-agar, gliserin, emulsi dan lainnya yang berbahaya bagi manusia. Industry halal harus memiliki standar tentang produk-produk halal, mempersiapkan, memiliki pijakan, menempatkan peralatan dan teknologi yang mumpuni dan melakukan sertifikasi halal sehingga tujuan nya dapat tercapai, sehingga apa yang di cita-citakan oleh para peneliti di Kanada sebesar 632 milyar dolar produk halal dapat dikonsumsi oleh masyarakat dunia per tahun (Bergeud et al 2016).

Angka ini belum tentu aman dari jumlah umat Islam dunia yang dirilis dan dipublikasikan oleh media Pojok Jakarta bahwa umat Islam yang dipublikasikan pada tanggal 24 Agustus 2020 total populasi Islam dunia pada tahun 2019 sebanyak 1,9 milyar, sedangkan populasi Kristen sebanyak 2,4 milyar. Populasi Islam mengalami pertumbuhan pesat. Pusat penelitian PEW yang berpusat di Washington D.C menyatakan bahwa populasi dunia akan tumbuh 32 persen pada tahun 2060 dan umat Islam diperkirakan akan tumbuh 70 persen, artinya umat Islam menempati peringkat ke dua setelah Kristen.

Industri halal pun dibangun dari dua sisi, sisi pertama yaitu non Islam dan sisi kedua yaitu umat Islam. Sisi pertama tentunya pro dan kontra terhadap industry halal, bagi yang kontra industry halal adalah pesaing yang diperhitungkan dalam era pasar bebas dan industry 4.0, akan mengurangi industry-industri kapitalis berkembang dan menguasai pasar. Doktrin agama Islam masuk kedalam kebijakan-kebijakan industry global, misalnya laranganlarangan minum-minuman beralkohol, mengkonsumsi obat-obatan terlarang bagi umat Islam berpengaruh terhadap industry minuman keras dan obat-obatan di Dunia. Sedangkan bagi yang pro industry halal adalah solusi masalah manusia dari kerusakan fisik, tatanan, lingkungan dan bangunan. Bagi umat Islam melalui doktrin agama yang terdiri dari al-amr dan an-Nahyu memberikan keuntungan tersendiri untuk mengembangkan industry halal, apalagi pasar global semakin intensif, setiap saat dengan perkembangan informasi digital dapat merubah ruang konsumsi, branding dan pemasaran serta pola konsumsi kelompok non Muslim. Di Turki politik identitas di antara Islamis dan Sekuler telah terjadi sangat dipengaruhi oleh pasar konsumen yang berkembang, "pasar untuk identitas", di konteks globalisasi tahun 1980-an dan 1990-an (Bergeud et al 2016). 


\section{IJMA: International Journal Mathla'ul Anwar of Halal Issues \\ Volume 1 Nomor 1- Maret 2021}

Di Malaysia total penjualan layanan makanan halal sekitar USD 7.5 milyar pada tahun 2010 karena meningkatnya pendapatan perkapita Negara tersebut. Peningkatan terhadap penjualan hasil industry halal tersebut bukan saja dipengaruhi dengan daya beli dan kekuasaan pemerintah tetapi meningkatnya urbanisasi di Malaysia terutama di kota-kota besarnya seperti Kualalumpur. Popularitas penjualan dan keyakinan terhadap industry pengelola pun nilainya sangat tinggi sehingga merubah prilaku konsumsi makanan makin meningkat misalnya di lingkungan kelurga di Malaysia.

Selain hal tersebut kepercayaan masyarakat begitu tinggi dengan pemerintah terhadap industry halal dengan membuat lembaga yang menerbitkan sertifikat halal bagi perusahaan. Promosi lainnya dan kegiatan pengembangan halal diselenggarakan oleh instansi pemerintahan seperti pengembangan industry halal coporation (HDC), selain sertifikasi halal, Malaysia juga menerapkan standar MS 1500, paduan umum tentang produksi, persiapan, penanganan dan penyimpanan halal yang mencakup kepatuhan terhadap Good Manufakturing Praktek (GMP) dan praktek kebersihan yang baik (GHP) oleh department standar Malaysia (SIRIM) (Yusuf \& Shukor, 2016).

Indonesia sebagai salah satu Negara yang memiliki penduduk beragama Islam terbesar di Dunia tentunya serius didalam mengembangkan pusat halal dunia. Salah satunya dilakukan oleh LPPOM MUI sebagai lembaga sertifikasi halal sekaligus mengemban tugas sebagai pemberi informasi public kepada mayarakat melalui produk bersertifikat halal dan salah satu program yang diluncurkannya yaitu Indonesia Halal Expo (INDHEX) 2011 kemudian tahun berikutnya dengan program yang sama 2012. Kegiatan tersebut merupakan perwujudan Undang-Undang No 23 tahun 1992 tentang kesehatan, Undang-Undang No 7 tahun 1996 tentang pangan, tentunya program tersebut sangat berguna bagi konsumen dan warga Negara Indonesia. Untuk mengetahui dan menentukan prilaku sebelum mengkonsumsi produk, sekaligus mendidik warga negaranya untuk meneliti sebelum membeli dan menggunakan produk-produk halal dan meyakinkan warga negaranya bahwa produk halal itu sehat, aman dan bergizi bagi warga negaranya.

Selain produk-produk halal usaha yang dilakukan oleh pemerintah dan MUI adalah mengembangkan ekonomi syariah, salah satu yang dilakukannya dalam bidang jasa keuangan yaitu perbankan syari'ah yaitu Bank Muamalat, pada tahun 2019 jasa keuangan syariah meraup 6,8 persen, walaupun pada nyatanya angka ini sangat kecil dibandingkan dengan jumlah penduduk yang beragama Islam di Indonesia. Pemerintahpun mendirikan lembaga khusua bagi penjaminan produk halal yaitu Badan Penyelenggara Penjamin Produk Halal (BPJPH) yang bertujuan mengakomodasi potensi pasar produk halal domestic yang sangat besar. Bergairahnya Industri halal di Indonesia tidak dapat dipisahkan dari kesadaran dan perkembangan keilmuan warganya, kesdaran tersebut setiap hari makin meluas berirungan dengan bangkitnya industry halal Indonesia.

Namun dari prestasi yang sudah ditorehkan oleh Indonesia menurut penulis masih jauh dari prioritas dan capaian tentang Industri halal yang diharapkan, Indonesia hanya 


\section{IJMA: International Journal Mathla'ul Anwar of Halal Issues \\ Volume 1 Nomor 1- Maret 2021}

berjibaku pengembangan produk halal secara lokal maupun nasional dan belum mencapai Internasional, hasilnya perkembangan industry halal di Indonesia tidak maksimal, bahkan tidak mampu bersaing dengan industry lainnya. Kelembagaan penjaminan Produk halal tidak melakukan trobosan baru untuk menghasilkan pengembangan industry halal di Indonesia. Peran MUI harus di tindaklanjuti dengan dibukanya industry industry halal baru sebagai industry terdepan di Indonesia.

Umat Islam Indonesia harus dibangkitkan dari tidurnya. Menurut penulis Industriindustri halal tidaklah hanya di kelola oleh pemerintah saja, tetapi sector swasta pun haruslah diberi ruang gerak yang luas. Seperti Malaysia merupakan pusat industry halal terbesar dan terkemuka dengan nilai ekspor tahunan 35,4 milyar ringgit Malaysia yang menyumbang 5,1 persen dari total ekspor Negara tersebut Negara ini menyediakan katering udara halal pertama di dunia di atas maskapai nasionalnya, Malaysia Airlines. Dengan prestasi ini tak mengherankan bila standar halal Malaysia kini banyak digunakan beberapa perusahaan multinasional global ternama, termasuk Nestlé, Colga te Palmo live, dan Unilever. Portofolio halal Malaysia juga telah berkembang di luar makanan dan minuman, merambah ke berbagai sektor lain, seperti kosmetik, logistik, farmasi, dan yang paling baru, pariwisata (Republika, 2021).

Sebasgai umat Islam terbesar di dunia seharusnya pemerintah Indonesia melalui MUI dan Kementrian agama mampu menggagas neegara-negara Muslim di luar Indonesia untuk membuat konfrensi bersama tentang produk halal secara global. Keputusan konfrensi tersebut merupakan bargaining ekonomi dan politik untuk menegaskan bahwa industry halal itu sudah mendunia. Keputusan dan kebijakan yang dibuat dapat berpengaruh terhadap perkembangan-perkembangan industry halal di dunia dari berbagai Negara.

Dengan payung hukum dunia yang dibuat bersama menciptakan system mekanisme pasar dan politik terhadap penerimaan Industri halal oleh Negara di Dunia dan juga berpengaruh terhadap Negara yang penduduk Muslimnya dinegara tersebut adalah minoritas akan memberikan psikologi ketauhidan yang tinggi terhadap adanya produk dan industry halal di negaranya. Penerapan sertifikat halal terhadap perusahaan-perusahaan dunia mendongkrak dan meligitimasi bahwa hala merupakan international brand yang dilebelkan guna mendapatkan dukungan dari umat Islam dunia dan juga umat non Islam.

Sejatinya bagi umat Islam industry halal tidak hanya membahas produk hasil industry tetapi juga harus disertai dengan bahan-bahan yang halal, management yang halal, penerapan upah yang halal system keuangan yang halal, mekanisme kerja yang halal, pembuatan undang-undang yang halal dan pemasaran yang halal, tetapi juga merupakan industry yang mengeluarkan serifikat jaminan halal diatas sertifikat yang lainnya. Tentunya di era globalisasi ini pembuatan labolatorium halal yang canggih sangatlah diharapkan dikarenakan komplek dan cepatnya arus produksi di perusahaan-perusahaan dunia. Pengkajian terhadap produk-produk yang dibuat oleh perusahaan guna mendapatkan sertifikat yang halal pun harus didukung dengan teknologi-teknologi yang canggih dan mumpuni. 


\section{Hasrat dan Logika Konsumsi}

Industry halal yang ada di dunia yang berkembang secara cepat dan mengambil peran secara menyeluruh tidaklah tiba-tiba muncul secara alamiah dan bukanlah semata-mata karena doktrin agama, mengapa karena Industri halal tidaklah bermain dengan teks kitab suci, tetapi peran manusia beragama lah yang menentukan maju dan mundurnya industry halal tersebut. Para ahli ekonomi syariah mungkin lupa bahwa industry halal itu tumbuh berdasarkan kepada keinginan manusia, entah itu secara individu maupun keompok. Terdapat dua kelompok manusia yaitu kelompok yang menginginkan industry halal sebagai salah satu industry yang ada di dunia dan kelompok lain beranggapan sebaliknya. Keinginan manusia menegaskan bahwa industry halal itu yang utama terletak pada sifat manusia itu sendiri yaitu hasrat.

Manusia hidup tentunya memiliki hasat, hasrat adalah keinginan yang berasal dari pikiran manusia karena melihat terdapat sesuatu yang menarik dari benda, fakta, sosial kemasyarakat, ilmu pengetahuan, kekuasaan, keindahan dll. Sifat hasrat adalah mimesis, meniru orang lain yaitu meniru keinginan orang lain terhadap suatu objek (Haryatmoko, 2003). Hasrat terjadi tidak sendiri dari individu manusia tersebut tetapi munculnya diakibatkan karena terdapat dua individu yang berkompetisi, individu yang berkompetisi tersebut disebut sebagai subjek dan perantara yang menginginkannya. Industry halal pada mulanya biasa menjadi menarik karena ada subjek yang menginginkannya, subjek menginginkannya didasarkan kepada hasrat (keinginan) karena trdapat hal-hal dalam persepsi subjek yaitu "sesuatu" yang lain dari yang diinginkan perantaran terhadap objek (Haryatmoko, 2016).

Hasrat dalam industry halal terletak dalam diri para konsumen dengan kebutuhan yang beragam, konsumen adalah yang utama dalam pengembangan industry halal, apa jadinya industry halal tanpa dukungan dari konsumen, oleh karena itu industry halal harus melihat konsumen di sebuah daerah maupun Negara, apa yang diinginkan oleh konsumen terhadap industry halal harus di lakukan, sebagai contoh di Rusia terdapat kaum Muslim yang menginginkan label di setiap makanan yang disajikan di super market, bagi kaum Muslim Rusia labelitas adalah hasrat menerapkan ajaran agama Islam, maka peran umat Islam untuk membangun industry halal adalah adanya lembaga penjamin prodak makanan halal, lembaga tersebut menganalisis dan memutuskan produk-produk makanan apa yang halal beserta sertifikasi halal yang diberikan kepada perusahan yang memproduksi maknanmakanan tersebut. Dan tentunya adanya lembaga pengkajian halal dan jaminan sertifikasi halal di Rusia menjadi menarik dan mempengaruhi industry-industri lainnya di Rusia. Semakin kencang hasrat umat Muslim Rusia menginginkan labelisasi halal maka secara otomatis berpengaruh bagi pemerintahan di Negara tersebut.

Hasrat manusia adalah kebutuhan yang beragam, tidak akan mungkin manusia kebutuhannya tunggal, semakin kencang arus globalisasi dan semakin mudahnya manusia 


\section{IJMA: International Journal Mathla'ul Anwar of Halal Issues \\ Volume 1 Nomor 1- Maret 2021}

mengakses dunia digital maka kebutuhan manusia pun semakin komplek, bahkan sebagian besar manusia mengikuti arah dunia digital yang tanpa henti bereaksi secara berantai, sehingga merubah pola hubungan antara konsumen dan objek konsumsi. Konsumen tidak lagi membeli barang karena manfaat yang terkandung didalamnya, tetapi terkait pula dengan pemaknaan dan symbol human life, serta makna makna lain yang muncul seperti keindahan, elegan, berbudaya serta seni. Pemaknaan tersebut pun terpengaruh oleh strata sosial dan kasta didalam diri manusia. Mencermati kebutuhan manusia tersebut maka peran industry halal adalah menciptakan produk yang aman dan memiliki nilai yang tinggi terhadap strata sosial dan gaya hidup elit. Tidaklah dilarang ketika pengusaha-pengusaha Muslim menciptakan produk-produk halal dan elit. Pengusaha Muslim misalnya membuat Tas yang elegan, bernilai yang mampu menyaingi tas merek Hermes yang dikonsumsi oleh para tokoh, konglomerat, artis yang bonafit.

Penulis menganalisis sesungguhnya hasrat yang terjadi terhadap industry halal di dunia dimunculkan pula oleh para pengusaha yaitu para pengusaha Muslim mampu memanipulasi tanda, mengarahkan para consumer pada konsumsi akan gambar, fakta, dan informasi yang diterima dengan realitas yang terjadi yaitu realitas yang komplek. Meyakinkan para consumer dengan label halal yang memiliki keunggulan dengan merek lainnya adalah manipulasi tanda, labelisasi bukanlah kebohongan tetapi lebih kepada memunculkan realitas dibalut dengan kesolehan didalam praktek pasar atas anjuran agama, pilihan manusia tentu berbeda, semakin kencang dan beragam berproduksi dan semakin banyak pilihan maka semakin antusias terhadap berbagai macam produk.

Pikiran manusia pun dipengaruhi oleh pemaknan yang dimanipulasi yang abstrak yang mengarahkan hasrat terhadap keinginan manusiawi. Lalu yang manakah yang mempengaruhi, dengan perkembangan dunia digital maka menurut penulis, hasratlah yang mempengaruhi pikiran manusia, hasrat merubah pikiran manusia secara tiba-tiba terkadang hasrat melebihi kondisi keuangan dan peran keluarga. Mengapa demikian karena seluruh perusahaan dan perdagangan mengiklankan produknya tanpa henti berbagai macam cara dilakukan baik itu di media TV, maupun media online, dengan kecanggihan dan kecerdikan iklan manusia tergiur dengan memunculkan rasa ingin tahu yang begitu tinggi, semakin manusia ingin tahu maka semakin mudah untuk termakan gossip ataupun rumor. Jebakan iklan sulit untuk dielakan karena iklan begitu progres, terkadang muncul sifat kekhawatiran begitu tinggi apabila tidak melakukan ataupun membeli produk yang diiklankan tersebut (Haryatmoko, 2016).

Dari pemaparan diatas sesungguhnya antara konsumen dengan para pengusaha Muslim memiliki hasrat yang berbeda tetapi walaupun terdapat perbedaan keduanya saling melengkapi dan membutuhkan. Bagi konsumen hasrat yang dibangun adalah keingintahuan, keindahan, pemaknaan, keragaman, strata sosial, serta identitas. Sedangkan bagi para pengusaha yang menciptakan Industri halal hasrat adalah manipulasi tanda dengan rasional dan sesuai dengan realitas yang diinginkan, bagi para pengusaha hasrat haruslah 


\section{IJMA: International Journal Mathla'ul Anwar of Halal Issues \\ Volume 1 Nomor 1- Maret 2021}

mengendalikan pikiran manusia, dan cara yang paling efektif mengendalikan pikiran manusia adalah dengan tayangan iklan yang terus menerus, iklan yang cerdas dan kreatif sehingga para konsumen tidak memiliki pikiran lain, pikiran mereka digiring untu menyetujui secara tidak sadar.

Selanjutnya industry halal harus peka terhadap logika konsumsi, karena logika konsumsi berhubungan dengan tatanan sosial an gaya bahasa konsumen, melihat apa yang diinginkan konsumen dalam nalarnya. Mengkonsumsi barang ataupun jasa pun tidak terlepas dari logika konsumsi, hal ini penting sekali diketahui oleh para penggeliat industry halal. Jean Baudrillard yang ditulis oleh haryatmoko dalam bukunya Membongkar Rejim Kepastian Pemikiran Kritis Post Strukturalis menjelaskan Baudrillard membagi empat macam logika konsumsi pertama Konsumsi sebagai system pertukaran, dalam logika ini mengandaikan dua proses yaitu konsumsi adalah system pertukaran yang sejajar dengan bahasa dan konsumsi sebagai status sosial.

Penjelasan konsumsi sejajar dengan bahasa adalah bahwa objek selalu dimanipulasi, pada mulanya barang itu biasa saja, tetapi ketika ada bahasa yang menjadi pristise maka barang tersebut menjadi sumber hasrat manusia, contohnya, awalnya masker adalah barang yang biasa saja, tetapi ketika umat manusia di Dunia terjangkit virus covid 19, maka masker menjadi legitimasi kekuasaan, bahkan orang nomor satu di Indonesia mengajak dan menegur warganya yang tidak menggunakan masker, masker adalah wajib digunakan, produksi masker meningkat tajam pada saat sekarang ini. Lalu konsumsi sebagai proses klasifikasi dan pembedaan sosial adalah bahwa konsumsi menjadi strategi dan alat strata sosial, misalnya seorang artis tidak mau dan merasa terhina ketika membeli barang di kaki lima, mereka membeli barang di mall yang terkenal dengan brand yang bergengsi, bahkan mereka membeli barang sampai ke luar negeri, mengapa demikian, hal ini menunjukan bahwa strata sosial mereka berbeda dengan yang lain, mereka menciptakannya dan dengan demikian mereka bisa berkumpul dengan para artis lainnya membentuk strata sosial yang berbeda dalam bahasa Baudrillard disebut dengan distinction (membedakan diri) (Haryatmoko, 2016).

kedua konsumsi menjamin tatanan tanda yaitu kenikmatan tidak lagi tampil sebagai tujuan tetapi sebagai proses dimana tujuan berada di tempat lain, justru konsumsi adalah memperbanyak kontak, relasi, mengeksploitasi secara sistematis kuasa dan pengetahuan, misalnya seorang pengusaha mengajak makan siang relasinya di sebuah rumah makan terkenal di Bali, tujuan pengusaha tersebut bukan semata kepada konsumsi makannya tetapi ia bertemu dengan status sosial yang berbeda untuk tujuan bisnis dan memperkuat bisnisnya. Perbedaan tersebut memang tidak alamiah diciptakan oleh pengusaha tersebut, yaitu mendefinisikan system konsumsi dengan membentuk hierarki, hanya manusia tertentu yang diinginkannya yang sama dengan dirinya.

Ketiga system konsumsi sebagai fungsi ideologis yaitu konsumsi dapat menggantikan ideologis dan menjamin integritas masyarakat, konsumsi adalah pusat 


\section{IJMA: International Journal Mathla'ul Anwar of Halal Issues \\ Volume 1 Nomor 1- Maret 2021}

keyakinan dan relasi sosial, tubuh, kulit, pakaian adalah kesenangan diri dan dibanggakan dipertontonkan memiliki keunggulan dan kelainan simbolik kekuasaan dari yang lainnya, menarik masyarakat, dipaksakan untuk beralih kepada apa yang dilakukannya, kebanggaan adalah menunjukan hasil dari yang ia lakukan dan masyarakat menyetujui apa yang dilakukannya. Sebagai contoh banyak kaum perempuan yang membeli obat pelangsing tubuh, bahkan harganyapun sangat mahal, setelah obat tersebut ia konsumsi maka tubuhnya menjadi langsing, ia mempertontonkan dan membicarakan kelangsingannya tersebut kepada masyarakat. Begitujuga dengan pemutih kulit, pakaian dipertontonkan dan memaksa menyetujui hierarkis sosial.

Keempat konsumsi budaya yaitu penanda dianggap petanda maksudnya adalah model pemahaman yang bias bisa jadi begitu tetapi sebetulnya yang dikonsumsi adalah hanya menunjukan petanda lain, budaya adalah aktifitas yang diulang-ulang, dilaksanakan dan diakui. Misalnya dalam rokok terdapat tulisan "merokok dapat menyebabkan kangker, impotensi, gangguan kehamilan dan janin" contoh tersebut adalah penanda yang dianggap petanda untuk terus merokok, bagi perokok himbauan pemerintah tersebut diketahui tetapi menjadi bagian untuk membagi-bagikan rokok nya kepada temannya atau orang lain untuk merokok bersama.

\section{KESIMPULAN}

Pada akhir tulisan ini penulis membuktikan bahwa Industry halal di Indonesia belumlah maksimal, peran pemerintah dan MUI dalam mengembangkan Industry halal di Indonesia masih lemah. Padahal potensi mengembangkan industry halal di Indonesia sangatlah tinggi dan memiliki peluang yang bagus. Salah satu keuntungan bangsa Indonesia apabila mengembangkan Industri halal terletak dari kuantitas jumlah penduduk Indonesia yang beragama Islam yang terbesar di dunia dan juga kuantitas jumlah penduduk Islam dunia yang menempati peringkat ke dua di dunia setelah Kristen, tetapi pertumbuhan penduduk muslim dunia sangat tinggi dari kalangan kaula muda. Seharusnya peluang ini dimanfaatkan oleh pemerintah Indonesia dengan memperluas industry halal, industry halal tidaklah melulu tentang produk makanan tapi dilain itu bisa dikembangkan pula jasa, lingkungan, parawisata, bioteknologi, manufaktur, pangan perdagangan, human life.

Kemudian daya dukung untuk pengembangan industry halal terletak dari dua hal yaitu hasrat dan logika konsumsi, Manusia hidup tentunya memiliki hasat, hasrat adalah keinginan yang berasal dari pikiran manusia karena melihat terdapat sesuatu yang menarik dari benda, fakta, sosial kemasyarakat, ilmu pengetahuan, kekuasaan, keindahan dll. Sifat hasrat adalah mimesis, meniru orang lain yaitu meniru keinginan orang lain terhadap suatu objek. Hasrat terjadi tidak sendiri dari individu manusia tersebut tetapi munculnya diakibatkan karena terdapat dua individu yang berkompetisi. Industry halal pada mulanya biasa menjadi menarik karena ada subjek yang menginginkannya, subjek menginginkannya didasarkan kepada hasrat (keinginan) karena trdapat hal-hal dalam persepsi subjek yaitu 
"sesuatu" yang lain dari yang diinginkan perantaran terhadap objek. Sedangkan logika konsumsi adalah adalah logika sosial dan logika hasrat para konsumen dengan nalarnya mensifati terhadap produk-produk yang diciptakan oleh Industri halal.

\section{DAFTAR PUSTAKA}

At-Thariqi, Ahmad, al-ahkam al ath 'imah fi asyari'ah al Islamiyah, Riyadh,1984

Ali, Muchtar,'konsep makanan halal dalam tinjauan syari'ah dan tanggung Jawab produk atas produsen industry halal", dalam Ahkam : Kementrian Agama republic Indonesia, vol XVI no 2 Juli 2016

Armanios, Febe \& Bogac Ergene, Halal Food a History, New york: oxford University press, 2018

Florence Bergeud-blackler, John Fischer \& John Lever, Halal Matters Islam, Politics and Markets In Global perspective, London \& New York: Routledge, 2016

Haryatmoko, Membongkar Rezim Kepastian: Pemikiran Kritis Post-Strukturalis, Yogyakarta: Kanisius, 2016

Haryatmoko, Etika Politik dan Kekuasaan, Jakarta: Kompas, 2003

www. Republica ci.id, berita dunia Islam, dalam Khazanah Geliat Industri Halal Di Negeri Jiran, diakses tanggal 29 Januari 2021

Yusuf, Asnidar Hadim, Syadiyah Abdul Shukor " Halal Certification vs Business Growth of Food Industry In Malaysia" dalam Jurnal of Economic, Business and Management Vol 4, No 3, March 2016 
